\title{
SUPPORTING LOCAL FOOD SYSTEM DEVELOPMENT THROUGH FOOD PRICE PREMIUM DONATIONS: A POLICY PROPOSAL
}

\author{
DAVID B. WILLIS* \\ Department of Agricultural and Environmental Sciences, Clemson University, Clemson, South Carolina \\ CARLOS E. CARPIO \\ Department of Agricultural and Applied Economics, Texas Tech University, Lubbock, Texas \\ KATHRYN A. BOYS \\ Department of Agricultural and Resource Economics, North Carolina State University, Raleigh, North Carolina
}

\begin{abstract}
This study investigates consumer preferences for a marketing system that improves integration of farmers into a local food system. Attribute-based methods are used to estimate consumer willingness to pay for a locally grown product that is bundled with a local food bank (LFB) donation. Estimates reveal that, on average, households are willing to pay $11 \%$ more for locally grown relative to nonlocal agricultural products. When the locally grown product attribute is combined with a donation to support a LFB, the premium nearly doubles. Results suggest that the proposed system could provide resources to strengthen local food distribution networks.
\end{abstract}

Keywords. Donation, food bank, local food system, locally grown, meat, produce, willingness to pay

JEL Classifications. Q13, Q18, D47

\section{Introduction}

In the United States, the sale of agricultural products marketed through "local" channels has dramatically increased in the past two decades. Nationally, the number of local farmers' markets has increased from 1,755 in 1994 to 8,144 in 2013 (U.S. Department of Agriculture, Agricultural Marketing Service, 2016). The number of major food retailers that specifically market local products has also grown rapidly (King, Gómez, and DiGiacomo, 2010). Considering both direct-to-consumer marketing and intermediated channel sales to restaurants, grocery stores, and regional distributors, total local food sales were estimated to

This project was supported by Agriculture and Food Research Initiative Competitive Grant No. 201167023-30124 from the U.S. Department of Agriculture, National Institute of Food and Agriculture. The authors would like to acknowledge Emily Jones her for her valuable research assistance.

*Corresponding author: e-mail: willis9@clemson.edu 
be $\$ 4.8$ billion in 2008 (Low and Vogel, 2011). The 2012 Census of Agriculture reported that national direct-to-consumer farm sales totaled $\$ 1.31$ billion in 2011 . This reflects a per capita spending of $\$ 4.17$ and an average growth in sales of $1.63 \%$ per annum since 2007 (Boys and Blank, forthcoming).

Despite strong consumer demand for their products, smaller farms find it difficult to compete for a share of this growing market. Although marketing channel challenges vary by product and setting, constraints including the limited available quantity, logistic considerations, and lack of price competitiveness negatively affect the ability of smaller producers to supply this market (Izumi et al., 2006; Vogt and Kaiser, 2008). Among these constraints, the relative inefficiency of smaller compared with larger farms in the transportation, distribution, and delivery of their product is a critical marketing challenge (Boys, Westray, and Fraser, 2012; Cantor and Strochlic, 2009).

Local farms can successfully compete, however, if they emphasize their product's unique characteristics or services and/or have access to processing and distribution centers (King, Gómez, and DiGiacomo, 2010). This article is part of a larger study evaluating the feasibility of introducing an integrated marketing system that links local farmers to farmers' markets and other local food retailers via a local food distribution system. One such model would be to consider using a local food bank's (LFB) transportation, storage, and processing centers, which are already well established as part of their core activities of providing access to healthy foods to those who cannot afford it. In exchange for their participation, the local food distributor (in this example, a food bank) would receive revenue generated by a price premium placed on locally grown products sold at any local retail market.

To be feasible, the system would need to be self-sustaining and provide both food system intermediaries and local farmers an opportunity to enhance their profitability. As an initial step in assessing the viability of such a program, we estimate the price premium consumers would be willing to pay at retail outlets for locally grown products if a portion of the purchase price is used as a donation to support an LFB. Specifically, we ask three questions: (1) How large are the price premiums consumers are willing to pay for local agricultural products? (2) How large a price premium are consumers willing to donate to support an LFB used as a distributor in a local food supply chain? (3) Are the local and donation attributes of a food purchase complements or substitutes? We also describe the implications of the findings for the feasibility of the proposed local food system (LFS).

It is important to mention that even though the estimated price premiums on food consumers are willing to donate to a food bank were obtained as part of a study evaluating the feasibility of using food banks as distributors in local food supply chains, the results of the study can be more generally used in assessing the use of price premiums on food products as a source of funding for food 
banks, independently of their participation as distributors of foods to mainstream markets.

\section{1. "Locally Grown” Food}

What is a "locally grown" product? Although the United States has no federal regulation governing the definition of "local," the U.S. Congress in the 2008 Food, Conservation, and Energy Act provided guidance about what is not local food. This legislation stipulates that for an agricultural product to be defined as locally grown "the total distance that a product can be transported must be less than 400 miles from its origin or within the state in which it is produced" (Food, Conservation, and Energy Act of 2008, section 6015). In practice, however, geopolitical boundaries commonly shape the boundaries of what is "local." This term can also be operationalized by distance, travel time, topographical or climatic features, the needs and perspectives of relevant stakeholders, and/or characteristics of key producers or the consumers (e.g., Dunne et al., 2011; Hand and Martinez, 2010; Ilbery et al., 2006; Ostrom, 2006). Others argue that practical realities of the local economy should shape the definition. ${ }^{1}$ On a larger geographic scale, consumers in some states have been found willing to pay more for in-state than out-of-state or regional food products (Burnett, Kuethe, and Price, 2011; Giraud, Bond, and Bond, 2005; Onken, Bernard, and Pesek, 2011), and local food marketing, production, and policy initiatives may be characterized on the state level (e.g., state farm and value-added promotion programs, some marketing orders and agreements; Boys and Blank, forthcoming). For the purposes of this study, "locally grown" is defined to be a product grown in the state of South Carolina, and "nonlocal" products are those produced out of state. ${ }^{2}$

Many studies have explored the factors that contribute to the recent trend of increased consumer preference for local foods relative to out-of-area or imported foods (e.g., Carpio and Isengildina-Massa, 2009; Loureiro and Hine, 2002; Onken, Bernard, and Pesek, 2011). A consistent theme in these studies is that despite strong interest for locally grown food products among consumer groups, these products are not always widely available. Small farms, ${ }^{3}$ which consumers perceive as being the source of products sold through "locally grown" markets, have numerous sales outlets. Direct-to-consumer outlets such as sales through farmers' markets or roadside stands; direct-to-institution outlets in which farms directly supply schools, hospitals, and other institutions; and

1 For example, Hultine et al. (2007) suggest that a small rural community might consider neighboring, food-producing areas within a certain radius (i.e., within 10 miles) as local. Alternatively, large urban centers could have a much-expanded radius of "local"; for residents of Chicago, farmers in Illinois, Wisconsin, Indiana, and Michigan could all be considered local.

2 Although this definition was provided to study respondents, we recognize that surveyed consumers may be personally guided by a different definition of "local."

3 Those with gross cash farm income less than \$350,000 (Hoppe and MacDonald, 2013). 
intermediated outlets through which farms supply restaurants, grocers, and regional distributors are the primary sales channels for these farms. Among these, direct-to-consumer outlets are highly preferred by small and many medium-sized farms (Low and Vogel, 2011). Among other benefits, these outlets offer farms flexibility to select the quality and quantity of products available for sale, freedom from contracts, and frequently higher per unit sales prices than other marketing channels. As such, of relevance to the proposed policy, products from small farms are generally well represented at farmers' markets.

The same is not true, however, of small-farm products sold through standard brick-and-mortar retailers. Retail stores offer small farms important benefits of access to different consumer segments and a guaranteed buyer, and thus they can help smooth the week-to-week income variability often experienced by heavy reliance on direct-marketing channels. Retailers, however, may stipulate that specific production practices be used (i.e., that the farm be certified to Good Agricultural Practices), commit to a specified volume of product, and satisfy additional requirements such as that the product be washed, weighed, labeled, and delivered to the retail outlet (Westray, 2012). Many small farmers find this burden too high relative to the unit prices they are offered, and they opt out of retail channels. This limits access to "locally grown" products for customers who do not have the means or inclination to travel to sites where they can be purchased directly and narrows the marketing channel options, and thus income and sales risk mitigation strategies, available to these farmers. The proposed policy would help to reduce the marketing burden on farmers and thus should help to increase the supply of products through this channel.

\subsection{Cause-Related Marketing}

In the United States, cause-related marketing (CRM) is the strategy of formulating and implementing a firm's marketing activities with a contribution to a designated charitable cause (Varadarajan and Menon, 1988). CRM strategies can be used to improve the visibility of a firm or brand; increase sales; improve brand differentiation, recognition, and/or image; or offset negative public opinion (Brønn and Vrioni, 2001; Varadarajan and Menon, 1988). An early example of cause marketing is the 1983 American Express campaign in which credit cards were issued that, when used, would donate a prespecified dollar amount toward the restoration of the Statue of Liberty and Ellis Island. This transaction-based strategy generated $\$ 1.7$ million in restoration funds (American Express, 2015) and significantly increased card use. American Express subsequently promoted three other charity campaigns tied to their credit cards with great success (Welsh, 1999). McManus and Bennet (2011) have also found that consumers are willing to pay a price premium for products that are related to social causes or public goods. In other successful CRM campaigns, firms have offered opportunities for joint promotions (Marks and Spencer, 2015) or have offered in-kind contributions of needed resources such as supplies, advertising, 
transportation, and staff expertise (Ellen, Mohr, and Webb, 2000; Liu and Ko, 2011).

\subsection{Donation Policies to Support Local Food Systems}

The approaches used in the donation programs described previously, or a variety of alternative strategies or business models, could be used to generate the financial support needed to further develop LFSs. In particular, an extensive and creative array of options have been proposed and tried to address LFS infrastructure challenges. Private or cooperatively owned farm stands and mobile, online, or brick-and-mortar stores specializing in locally sourced products are among the most common approaches. Some food wholesalers and distributors have committed to procuring a portion of their produce from local suppliers (e.g., Limehouse Produce; Hughes, Chrissy, and Boys, 2014), and some larger food retailers such as Walmart have started local sourcing programs of their own (Swanson, 2013). Alternatively, local food hubs are emerging to offer a combination of production, aggregation, distribution, and marketing services to help smaller farmers access additional markets (Barham et al., 2012).

The food system donations collected through the proposed program could be used to develop or strengthen small-farm marketing through or to each of these channels. All these alternatives, however, have well-recognized limitations in either the extent to which they improve consumer access to foods produced in their local region or in the prices farmers ultimately receive for their products. In addition, most of these alternatives require new physical infrastructure. One option, which, to date, has received very limited consideration, is the possibility of using the food distribution infrastructure of existing food banks to help store and distribute an LFS's products. This alternative is explored herein.

\subsubsection{Food Banks and Locally Grown Food}

Food banks are nonprofit organizations created to distribute donated food directly to individuals or agencies that feed food-insecure individuals, often within a specified geographic region. Food banks provide an important function by serving a small, low-income subset of a community's population. To accomplish this, food banks maintain facilities where food is donated, collected, sorted, and then distributed through their supply network to churches, soup kitchens, homeless shelters, government organizations, schools, and other organizations. These same distribution network nodes often serve as collection points during food drives.

Recently, community-supported agriculture (CSA) organizations and individual farmers have become additional sources of food bank donations. CSAs offer a marketing arrangement in which consumers purchase a membership or subscription to a particular farm or a cooperative of farms, in return for a box (or other predetermined quantity) of that farm's output (i.e., produce) on a weekly or monthly schedule throughout the harvesting season. When a CSA or a farm 
has excess output, they may donate it to an LFB. ${ }^{4}$ In the United States, however, this is not a widespread practice.

Food banks have not traditionally been considered among potential contributors to local agricultural economic development because they tend to be recipients rather than sources of supply for food donation policies. There are instances, however, in which food banks have helped local farms market their production. Robinson et al. (2007) introduce a case in which a food bank provided benefits to the local agricultural community. Beyond its primary mission as an emergency food assistance system, South Carolina's Lowcountry Food Bank provides delivery, storage, inspection, and disposal services to local farmers to increase the distribution of their products into local retail markets. The success of the Lowcountry Food Bank initiative suggests that food banks have the willingness and capacity to support their LFS. This case further motivates the need to investigate the feasibility of establishing an integrated multicounty marketing network that could potentially benefit both local farmers and participating food banks.

In the policy proposed herein, food system intermediaries provide logistics and distribution functions between farms and food retailers by using their marketing networks, transportation system, and storage to improve the distribution of food between these market stakeholders. In exchange, the participating market intermediary would be compensated by price premiums (monetary donations) paid by consumers who purchase locally grown foods at participating local retailers. In exchange for their donation, and in addition to supporting their LFS, customers benefit by having access to the same locally grown products at more convenient locations.

\section{Data Collection and Methods}

To address our research objectives, two surveys were developed, pretested, and distributed to randomly selected households. Each survey was organized into four sections that collected the following information about the household: (1) current consumption of agricultural products, (2) knowledge and opinions about local foods and LFBs, (3) responses to a set of stated choice experiments, and (4) socioeconomic demographic characteristics including respondent age, gender, highest achieved education level, number of years lived in the area, and whether they have worked in either the agricultural or nonprofit industries.

The two surveys were identical in design except for the stated choice experiments; one version focused on produce (fruits and vegetables), and

4 Taylor's Fresh Organics farm and the Maryland Food Bank (Maryland Food Bank, 2015); Regional Food Bank of Northeastern New York (Regional Food Bank of Northeastern New York, 2015); Astoria CSA and the Astoria Food Bank (in New York; Harvest Astoria, 2015); and Helsing Junction Farm and the CSA Food Bank Program (in Washington State; Helsing Junction Farm, 2015) are examples of such programs in the United States. 
Table 1. Choice Experiment

\begin{tabular}{ll}
\hline \hline Attribute & Level \\
\hline Growing location & Local (South Carolina grown) \\
& Out of state \\
Product price & Average price \\
& $10 \%$ more than average \\
& $20 \%$ more than average \\
& $30 \%$ more than average \\
& $40 \%$ more than average \\
Donation aspect & Included donation \\
& None (donation not included) \\
\hline \hline
\end{tabular}

the other focused on animal products (meat, poultry, eggs, and dairy). The experiments were designed to gain information on consumer preferences for local foods and donations to food banks by empirically simulating purchasing behavior when the levels of specific product attributes differ. The choice experiment section began by asking respondents to think about their average trip to the grocery store, farmers market, or other point commonly used to purchase agricultural products. Differing from prior research in which participants were given specific products to evaluate, participants were instructed to report their favorite or most commonly purchased agricultural product (dependent on survey version: fruit/vegetable or animal product), the quantity of their favorite product they normally purchased per trip, and the average price paid per unit.

The two products differed across three attributes relevant to this study: growing location (local vs. nonlocal), price relative to average price paid (five potential prices), and whether the product price included an implicit food system donation. We then varied the three attributes of their favorite product and asked the respondents to choose which version of their product (A, B, or neither) they would purchase if given the choice (see Table A1 in the Appendix for a sample choice question). Consumers were also instructed to assume that the products shown in the choice experiments were identical in terms of all other attributes, such as size, color, freshness, and so forth, and were reminded about their budget constraint.

Note that in contrast to other studies using attribute-based methods, the price attribute does not use price/unit but rather prices relative to the average price per unit (in percentage terms) of the most commonly purchased or favorite food product. Relative prices are used because we are trying to measure consumers' average willingness to pay (WTP) for attributes among a variety of produce and animal products.

Table 1 presents the three product attributes and the levels considered within each attribute used in this study. SAS software was used to create the experimental question design. For each product, the potential level of each of 
the three attributes was utilized to generate eight comparison sets from 190 possible unique attribute-level comparisons using SAS's D-Optimal criteria. The number of choice sets was restricted to eight to keep the survey manageable, understandable, and minimize respondent fatigue. The same eight choices were presented to each surveyed respondent. The product attribute levels for each of the eight choice comparisons developed to estimate consumer WTP for the donation and/or locally grown attribute are reported in Table A2 (see the Appendix). The survey instrument was pretested using a focus group, and the survey response time ranged from 15 to 20 minutes.

Paper copies of the survey were distributed by mail to randomly selected households in the upstate region of South Carolina. ${ }^{5}$ The agricultural production environment made the region particularly appealing for this study; production within the region is very diverse and has a long temperate season and, as such, offers the potential to satisfy much demand for "local" produce and animal products. The upstate region is home to 1.2 million individuals living in three metropolitan areas, numerous smaller cities, and a few remote rural areas. The area's residents are diverse in economic standing and educational attainment and reflect an excellent cross section of food consumers. The region was also selected because of the stated interest of the LFBs to participate in innovative programs.

To encourage a high participation rate, the total design method recommended by Dillman, Smyth, and Christian (2009) was followed. The first mailing was in June 2012 and included an introductory cover letter and a survey. Two weeks later, a reminder card was mailed to all nonrespondents. Finally, 2 weeks following the reminder card, a cover letter and survey were resent to all remaining nonrespondents. There were 337 surveys returned for incorrect addresses, and 61 returned surveys were discarded because they were incomplete. A total of 340 completed surveys were returned and are used in this analysis. ${ }^{6}$

To assess the representativeness of our sample, we compared the characteristics of the region's population with that of the sample. The summary demographic characteristics for the survey sample are compared with population census statistics for South Carolina's upstate area in Table 2. The educational attainment of respondents is higher than that of the region's population. The sample is also slightly older and has a higher proportion of white individuals and females than the region's population. Sample household size is very close to

5 The region of upstate South Carolina was defined to include the counties of Abbeville, Anderson, Cherokee, Chester, Greenville, Greenwood, Lancaster, Laurens, McCormick, Oconee, Pickens, Spartanburg, Union, and York. Combined, this area encompasses approximately $37 \%$ of South Carolina's total population. Three-thousand copies of each of the produce and animal product surveys were distributed.

6 Although this did not yield a high response rate, low response rates have been reported in a number of recent studies (e.g., Pew Research Center, 2012). Moreover, several recent studies have found a very weak or nonexistent relation between low response rates and low survey accuracy (Curtis, Presser, and Singer, 2000; Holbrook, Krosnick, and Pfent, 2007; Keeter et al., 2006; Pew Research Center, 2012). 
Table 2. Comparison of Sociodemographic Characteristics of Survey Respondents and Upstate South Carolina's Population

\begin{tabular}{lll}
\hline \hline Sociodemographic Characteristic & Respondents & Regional Population $^{\mathrm{a}}$ \\
\hline Age: mean age for population 20 years and older & 52.0 & 48.5 \\
Gender: female & $61.1 \%$ & $52.2 \%$ \\
Household income: median household income & $\$ 40,000-\$ 60,000$ & $\$ 44,590$ \\
Household size: persons per household & 2.44 & 2.53 \\
Education: some college education & $77.2 \%$ & $51.1 \%$ \\
Race/ethnicity: white/Caucasian & $86.7 \%$ & $77.9 \%$ \\
\hline \hline
\end{tabular}

a Source: U.S. Census Bureau (2016a, 2016b).

that of upstate, and the sampled median household income interval contains the median household income in the population.

\section{Theoretical and Empirical Models}

Choices made by survey respondents were analyzed using the random utility model. The utility of each choice depends on the observable product attributes (price premium, donation, and growing location). For individual $i$ choosing between $j$ alternatives in choice occasion $t$, the utility of choice $j\left(U_{i j t}\right)$ is

$$
U_{i j t}=V_{i j t}+\varepsilon_{i j t},
$$

where $i=1, \ldots, I ; j=1, \ldots, J ; t=1, \ldots, 8 ; V_{i j t}$ is the portion of utility that includes only observed attributes; and $\varepsilon_{i j t}$ reflects the effect of the factors not captured by $V_{i j t}$ (e.g., consumers' habits, perceptions, etc.). In the context of this study, the index $t$ is used to denote the chronological choice order of the eight choice questions provided to each respondent. Assuming the usual linear functional form for the parameters in the deterministic component of utility, equation (1) can be rewritten as

$$
U_{i j t}=\beta_{i}^{\prime} x_{i j t}+\varepsilon_{i j t},
$$

where $\beta_{i}$ is the $\mathrm{K} \times 1$ vector of utility parameters corresponding to $\mathrm{K}$ choice attributes, with individual-specific parameters, and $x_{i j t}$ is the $\mathrm{K} \times 1$ vector of the choice attributes of the alternative $j$ at each choice the individual $i$ makes. Assuming each $\varepsilon_{i j t}$ is an independently and identically distributed extreme value with the cumulative distribution function, $F\left(\varepsilon_{i j t}\right)=e^{-e^{-\varepsilon_{i j t}}}$, the probability that consumer $i$ chooses alternative $j$ in choice occasion $t$, conditional on the coefficient vector $\boldsymbol{\beta}_{\boldsymbol{i}}$ is (Revelt and Train, 1998)

$$
P_{i j t}\left(\boldsymbol{\beta}_{i}\right)=\frac{e^{\boldsymbol{\beta}_{i}{ }^{\prime} X_{i j t}}}{\sum_{j} e^{\boldsymbol{\beta}^{\prime} \boldsymbol{X}_{i j t}}} .
$$


Because the same consumer makes several choices (eight), the probability of each consumer's sequence of observed choices needs to be considered. Let $h(i, t)$ denote the specific alternative $j$ that consumer $i$ selects in choice occasion $t$. Conditional on $\boldsymbol{\beta}_{\boldsymbol{i}}$, the probability of consumer $i$ 's observed sequence of choices over all choice occasions is (Train, 1998)

$$
S_{i}\left(\boldsymbol{\beta}_{\boldsymbol{i}}\right)=\prod_{t} P_{i h(i, t) t}\left(\boldsymbol{\beta}_{\boldsymbol{i}}\right)
$$

The coefficient vector $\boldsymbol{\beta}_{\boldsymbol{i}}$ is unobserved for each consumer $i$ and varies in the population with density $f\left(\boldsymbol{\beta}_{\boldsymbol{i}} \mid \boldsymbol{\theta}\right)$, where $\boldsymbol{\theta}$ represents the true parameters of the distribution of $\boldsymbol{\beta}_{\boldsymbol{i}}$. Therefore, the unconditional probability of the observed choice sequence is

$$
P_{i}(\boldsymbol{\theta})=\int S_{i}\left(\boldsymbol{\beta}_{\boldsymbol{i}}\right) f\left(\boldsymbol{\beta}_{\boldsymbol{i}} \mid \boldsymbol{\theta}\right) d \boldsymbol{\beta}_{\boldsymbol{i}} .
$$

Because the integral in equation (5) cannot be calculated analytically, estimation is carried out using simulated maximum likelihood (ML) procedures (Rigby and Burton, 2006; Train, 1998, 2003). Contrasting with the standard conditional logit model, consumer preferences apply to each choice situation and vary across consumers. Moreover, as shown in Train (2003), this version of the mixed logit model allows for correlation of choices for the same consumer. The mixed logit models were estimated using Matlab programs made available by Train (2015).

With regard to the distribution of the coefficients in $\boldsymbol{\beta}_{\boldsymbol{i}}$, the price coefficient is specified to be fixed. The distribution for the coefficients of all nonprice attributes was assumed to be normal because it is difficult to determine a priori how consumers perceive specific attributes. That is, individual $\boldsymbol{\beta}_{\boldsymbol{i}}$ coefficients may take on positive or negative values. Given these assumptions, the $\boldsymbol{\beta}_{\boldsymbol{i}}$ parameters can be viewed as utility coefficients that can be transformed into WTP measures for specific attributes ${ }^{7}$ that are also normally distributed (Hensher, Shore, and Train, 2005; Train, 1998, 2003).

In addition to estimating mean WTP values, by making full use of the results derivable from a mixed logit model, it is possible to estimate the entire WTP distributions using a conditional distribution approach (Hess, 2007; Revelt and Train, 1999). Applying Bayes's rule, the density of each $\boldsymbol{\beta}_{\boldsymbol{i}}$ conditional on the individual's sequence of choices and the population parameters is given by

$$
h\left(\boldsymbol{\beta}_{\boldsymbol{i}} \mid \boldsymbol{\theta}\right)=\frac{S_{i}\left(\boldsymbol{\beta}_{\boldsymbol{i}}\right) f\left(\boldsymbol{\beta}_{\boldsymbol{i}} \mid \boldsymbol{\theta}\right)}{P_{i}(\boldsymbol{\theta})} .
$$

7 Calculated as the negative of the ratio of a specific product attribute coefficient to the price coefficient. 
If $k\left(\boldsymbol{\beta}_{\boldsymbol{i}}\right)$ is a function of $\boldsymbol{\beta}_{\boldsymbol{i}}$ (e.g., the WTP values for each attribute), then the expected value of $k\left(\boldsymbol{\beta}_{\boldsymbol{i}}\right)$ is

$$
E\left(\boldsymbol{k}\left(\boldsymbol{\beta}_{\boldsymbol{i}}\right) \mid \boldsymbol{\theta}\right)=\frac{\int \boldsymbol{k}\left(\boldsymbol{\beta}_{\boldsymbol{i}}\right) S_{i}\left(\boldsymbol{\beta}_{\boldsymbol{i}}\right) f\left(\boldsymbol{\beta}_{\boldsymbol{i}} \mid \boldsymbol{\theta}\right) d \boldsymbol{\beta}_{\boldsymbol{i}}}{P_{i}(\boldsymbol{\theta})},
$$

which is approximated by

$$
\widehat{k\left(\boldsymbol{\beta}_{\boldsymbol{i}}\right)}=\frac{\sum_{r} \boldsymbol{k}\left(\boldsymbol{\beta}_{\boldsymbol{i}}\right) S_{i}\left(\boldsymbol{\beta}_{i}^{r}\right)}{\sum_{r} S_{i}\left(\boldsymbol{\beta}_{i}^{r}\right)}
$$

where $\boldsymbol{\beta}_{i}^{r}$ is the $r$ th draw from the population density $f\left(\boldsymbol{\beta}_{\boldsymbol{i}} \mid \boldsymbol{\theta}\right)$. The individual $\widehat{k\left(\boldsymbol{\beta}_{\boldsymbol{i}}\right)}$ estimated values can subsequently be used to estimate distributional statistics across respondents (Hess, 2007). The stability of the estimated distributions was verified using various sizes for the number of sample draws. The empirical results are based on 1,000 draws.

It should be noted that the ML procedure provides consistent parameter estimates even with nonrandom samples such as those obtained because of survey nonresponse, as long as the model is correctly specified and the nonresponse mechanism is only a function of explanatory variables or if the nonresponse mechanism is independent of the outcome and the explanatory variables (Wooldridge, 2002). Hence, several formal model specification tests were conducted to ensure that these conditions were satisfied (see Section 4).

Finally, model validity is a concern because our sample size of 340 individuals is relatively small, which could result in a model that is not representative of the population (Qushim et al., 2016). Monte Carlo (MC) simulation results from a study by Cherchi and de Dios Ortúzar (2008) suggest that in the case of the mixed logit model used with data obtained from choice experiments, model validity is a function of both the number of individuals participating in the experiments and the number of choices given to individuals. The MC simulation results from the Cherchi and de Dios Ortúzar's study also shows that mixed logit models with a very low number of individuals (only 50) and four choice experiments are able to generate models with parameters that are not statistically different from the true population parameter values and are able to correctly reproduce random heterogeneity (Cherchi and de Dios Ortúzar, 2008, pp. 121-22). Thus, these results suggest that our sample size consisting of 340 individuals and eight choices per individual may result in valid model estimation results.

\section{Results and Discussion}

\subsection{Basic Mixed Logit Results}

The estimated parameter values for two mixed logit model specifications that only include product attributes (ignoring demographic factors) are reported in Table 3. In model 1, the effect of the product attributes on consumer utility 
Table 3. Basic Mixed Logit Model Results

\begin{tabular}{|c|c|c|c|c|}
\hline \multirow[b]{2}{*}{ Variable } & \multicolumn{2}{|c|}{ Model 1} & \multicolumn{2}{|c|}{ Model 2} \\
\hline & Mean & $\begin{array}{l}\text { Standard } \\
\text { Deviation }\end{array}$ & Mean & $\begin{array}{l}\text { Standard } \\
\text { Deviation }\end{array}$ \\
\hline Price & $\begin{array}{c}-6.791^{* * *} \\
(0.327)\end{array}$ & & $\begin{array}{c}-5.760^{* * *} \\
(0.400)\end{array}$ & \\
\hline Asc & $\begin{array}{c}-8.855^{* * *} \\
(0.407)\end{array}$ & $\begin{array}{l}1.650^{* * *} \\
(0.145)\end{array}$ & $\begin{array}{c}-7.900^{* * *} \\
(0.501)\end{array}$ & $\begin{array}{l}1.661^{* * *} \\
(0.145)\end{array}$ \\
\hline Local & $\begin{array}{l}0.768^{* * *} \\
(0.131)\end{array}$ & $\begin{array}{l}0.925^{* * *} \\
(0.153)\end{array}$ & $\begin{array}{l}0.619^{* * *} \\
(0.157)\end{array}$ & $\begin{array}{l}0.917^{* * *} \\
(0.153)\end{array}$ \\
\hline Donation & $\begin{array}{c}0.097 \\
(0.095)\end{array}$ & $\begin{array}{l}0.724^{* * *} \\
(0.130)\end{array}$ & $\begin{array}{r}-0.034 \\
(0.121)\end{array}$ & $\begin{array}{l}0.735^{* * *} \\
(0.130)\end{array}$ \\
\hline Local $\times$ donation & $\begin{array}{l}0.588^{* * *} \\
(0.138)\end{array}$ & $\begin{array}{l}0.934^{* * *} \\
(0.145)\end{array}$ & $\begin{array}{l}0.596^{* * *} \\
(0.138)\end{array}$ & $\begin{array}{l}0.926^{* * *} \\
(0.145)\end{array}$ \\
\hline Produce $\times$ price & & & $\begin{array}{l}-2.415^{* * *} \\
(0.611)\end{array}$ & \\
\hline Produce $\times$ asc & & & $\begin{array}{l}-2.286^{* * *} \\
(0.726)\end{array}$ & \\
\hline Produce $\times$ local & & & $\begin{array}{r}0.336^{*} \\
(0.196)\end{array}$ & \\
\hline Produce $\times$ donation & & & $\begin{array}{r}0.294^{*} \\
(0.165)\end{array}$ & \\
\hline $\begin{array}{l}\text { Log likelihood (LL) } \\
\text { LL from standard logit model }\end{array}$ & & & & \\
\hline
\end{tabular}

Notes: Asc is the alternative specific constant for "neither" option; produce is the fruit/vegetable survey dummy. Asterisks (***,**, and ${ }^{*}$ ) denote two-tail statistical significance at the $1 \%, 5 \%$, and $10 \%$ levels, respectively. Number of individuals $=340$. Number of observations $=2,640$.

are assumed to be identical for both produce (fruits and vegetables) and animal products. The validity of this assumption is tested in model 2 by introducing an agricultural produce dummy variable (produce) and interacting it with the three product attribute variables (growing location, price, donation) to estimate potential differences in product attribute on the decision to purchase animal products versus produce products. The variable "alternative specific constant" $($ asc) is used to denote the "neither" option.

It is important to note that an interaction term between the local and donation attributes (local $\times$ donation) is included in both models to evaluate the possible of complementarity or substitutability relation between these two attributes in the purchasing decision. The type of relationship between the two attributes can shed light on consumers' preferences toward price premiums on local and nonlocal foods as payment vehicles for donations to food banks.

A log-likelihood ratio test was used to compare the restricted model (model 1) with the unrestricted model (model 2), where the restricted model hypothesizes that the effects of product attributes on consumer utility are identical for produce and animal products. The null hypothesis that the restrictions are valid was 
rejected $\left(\chi^{2}=20.2, P<0.01\right.$, degrees of freedom $\left.=4\right) .{ }^{8}$ Focusing on the model 2 interaction parameters, two of the four parameters are significant at the 0.01 level, and the other two are significant at the 0.10 level. This is strong evidence that the effect of product attributes differ by agricultural product type.

The negative coefficient for asc was expected and reflects that consumers strongly prefer to purchase (either A or B) than to not purchase a product. The consumer's indirect utility is decreased if when given a choice, no purchase is made and the consumer decides to keep her dollars in her wallet. Also expected are the negative price parameters, which reflect consumer preference to purchase cheaper products when all other product attributes are identical. The significant and positive coefficient on the local parameter indicates that consumers prefer locally grown over out-of-state products when all other attributes are equal. Moreover, the preference for the local attribute is greater for produce than for animal products as reflected by the positive value for the produce slope shifter in model 2.

If for a specific product attribute, the mean coefficient value is insignificant, then mean preferences are at or near zero. This is the case for the mean donation coefficient values reported for models 1 and 2. However, in model 2 where the produce dummy interacts with product attributes, the interaction between produce and donation is significant and reveals a consumer preference for making a donation when purchasing produce relative to doing so through purchasing an animal product.

Further, the positive and significant interaction between local and donation implies a complementarity relationship between these product attributes. Hence, consumers have a stronger preference to donate when purchasing locally grown products than when purchasing nonlocal products. However, this result does not necessarily imply consumers' unwillingness to donate to LFBs but only evidence of weak preferences for the use of premiums on nonlocal foods as a payment vehicle for donations to LFBs.

\subsubsection{Willingness-to-Pay Distributions}

Table 4 reports the estimated mean WTP values for the local and donation attributes for each agricultural product type. In percentage terms, consumers' mean WTP to pay for a local product that does not include a donation differs minimally between produce (fruits and vegetables) and animal products $(11.68 \%$ vs. $10.75 \%$ ). In contrast, consumers' WTP for the donation attribute, in the absence of the local attribute, is more than six times larger for produce than animal products $(3.69 \%$ vs. $0.59 \%)$. When considered together, this evidence suggests that a strong complementarity relationship exists between the donation

8 In model 2, all parameters corresponding to interaction terms between the produce dummy and attributes are assumed fixed. Models that assumed the coefficients of these interactions were random did not yield statistically significant results. Model 2 also excludes the interaction between the produce dummy and the local $\times$ donation variable because it was found to be insignificant. 
Table 4. Estimated Willingness-to-Pay (WTP) Distributions for Product Attributes (\%)

\begin{tabular}{|c|c|c|c|c|c|}
\hline \multicolumn{3}{|c|}{ Fruits and Vegetables } & \multicolumn{3}{|c|}{ Animal Products } \\
\hline $\begin{array}{l}\text { Local, No } \\
\text { Donation }\end{array}$ & $\begin{array}{l}\text { Donation, } \\
\text { Not Local }\end{array}$ & $\begin{array}{l}\text { Local }+ \\
\text { Donation }\end{array}$ & $\begin{array}{l}\text { Local, No } \\
\text { Donation }\end{array}$ & $\begin{array}{l}\text { Donation, } \\
\text { Not Local }\end{array}$ & $\begin{array}{l}\text { Local }+ \\
\text { Donation }\end{array}$ \\
\hline $\begin{array}{l}11.68 \\
(11.05,12.31) \\
{[1.23,21.04]}\end{array}$ & $\begin{array}{l}3.69 \\
(3.20,4.18) \\
{[-6.27,12.86]}\end{array}$ & $\begin{array}{l}22.33 \\
(20.95,23.71) \\
{[-1.00,45.69]}\end{array}$ & $\begin{array}{l}10.75 \\
(9.85,11.65) \\
{[-4.08,24.02]}\end{array}$ & $\begin{array}{l}0.59 \\
(-0.10,1.29) \\
{[-14.00,} \\
13.14]\end{array}$ & $\begin{array}{l}20.50 \\
(18.53,22.47) \\
{[-12.37,} \\
53.91]\end{array}$ \\
\hline
\end{tabular}

Notes: Values in parentheses represent the upper and lower bounds for a $95 \%$ confidence interval for mean WTP. Bracketed values represent the 2.5th and 97.5th percentiles of the distribution of individual WTP values.

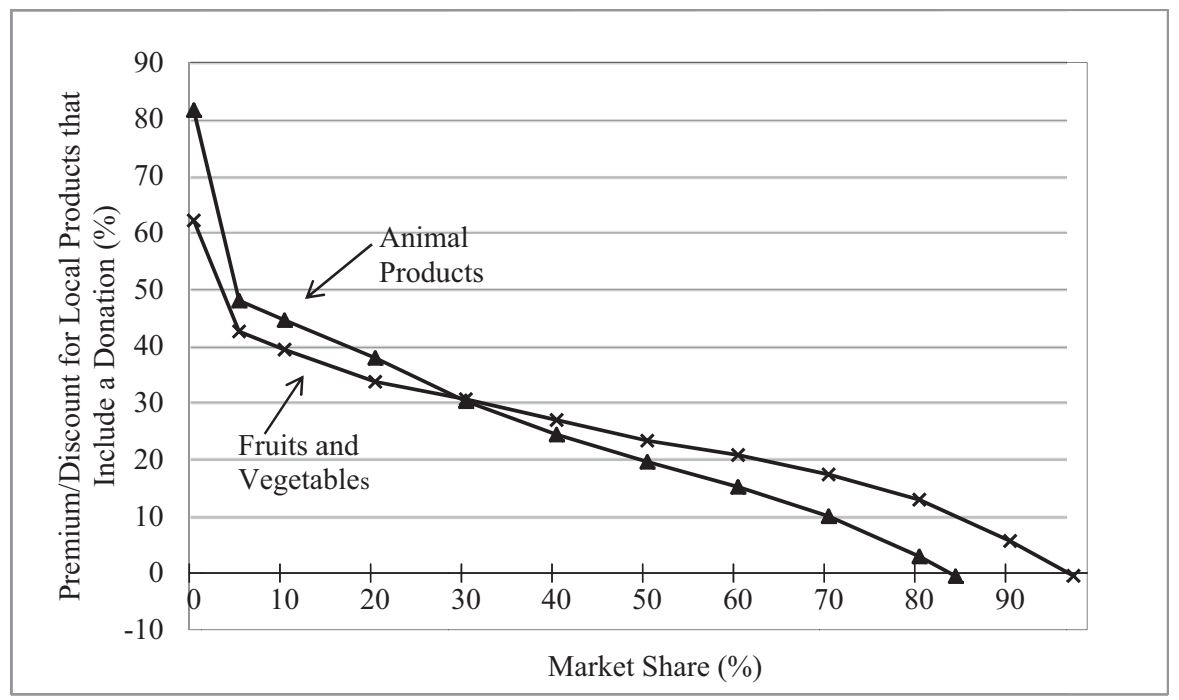

Figure 1. Willingness-to-Pay Price Premiums for Locally Grown Products That Include a Local Food System Donation

and local attributes. Relative to a product having only the local attribute, the mean WTP premium for both products nearly doubles when a product is both local and includes a donation.

Using the reported average price of $\$ 1.47 / \mathrm{lb}$. for produce and $\$ 3.11 / \mathrm{lb}$. for animal products, the mean WTP premium values for locally grown with donation correspond to per pound values of $\$ 0.33$ and $\$ 0.64$ for produce and animal products, respectively. In comparison, the WTP premium values for local products without a donation included were $\$ 0.17$ and $\$ 0.33$ per pound for produce and animal products, respectively.

Figure 1 presents the simulated demand equations for both local products with the donation attribute using the estimated WTP distributions. Points on 
Table 5. Results of Mixed Logit Model with Sociodemographic Variables

\begin{tabular}{|c|c|c|c|c|}
\hline \multirow[b]{2}{*}{ Variable } & \multicolumn{2}{|c|}{ Mean Coefficient } & \multicolumn{2}{|c|}{$\begin{array}{c}\text { Standard Deviation } \\
\text { Coefficient }\end{array}$} \\
\hline & $\begin{array}{l}\text { Parameter } \\
\text { Estimate }\end{array}$ & $\begin{array}{l}\text { Standard } \\
\text { Error }\end{array}$ & $\begin{array}{l}\text { Parameter } \\
\text { Estimate }\end{array}$ & $\begin{array}{l}\text { Standard } \\
\text { Error }\end{array}$ \\
\hline Price & $-5.758^{* * *}$ & 0.400 & & \\
\hline$A s c$ & $-7.873^{* * *}$ & 0.500 & $1.624^{* * *}$ & 0.143 \\
\hline Local & $1.565^{* * *}$ & 0.681 & $0.723^{* * *}$ & 0.176 \\
\hline Donation & $1.323^{* * *}$ & 0.568 & $0.627^{* * *}$ & 0.145 \\
\hline Local $\times$ donation & $0.595^{* * *}$ & 0.141 & $1.065^{* * *}$ & 0.138 \\
\hline Produce $\times$ price & $-2.417^{* * *}$ & 0.611 & & \\
\hline Produce $\times$ asc & $-2.295^{* * *}$ & 0.726 & & \\
\hline Produce $\times$ local & 0.233 & 0.192 & & \\
\hline Produce $\times$ donation & $0.227^{*}$ & 0.163 & & \\
\hline Income $\$ 40 \mathrm{~K}-\$ 80 \mathrm{~K} \times$ local & $0.608^{* * *}$ & 0.224 & & \\
\hline Income $>\$ 80 \mathrm{~K} \times$ local & $0.838^{* * *}$ & 0.276 & & \\
\hline Female $\times$ local & $0.518^{* * *}$ & 0.192 & & \\
\hline Age $\times$ local & $-0.017^{* * *}$ & 0.007 & & \\
\hline White $\times$ local & -0.129 & 0.297 & & \\
\hline Members $\times$ local & $-0.276^{* * *}$ & 0.082 & & \\
\hline Education $\times$ local & 0.054 & 0.255 & & \\
\hline Income $\$ 40 \mathrm{~K}-\$ 80 \mathrm{~K} \times$ donation & 0.145 & 0.191 & & \\
\hline Income $>80 \mathrm{~K} \times$ donation & 0.262 & 0.231 & & \\
\hline Female $\times$ donation & -0.090 & 0.164 & & \\
\hline Age $\times$ donation & $-0.020^{* * *}$ & 0.006 & & \\
\hline White $\times$ donation & 0.060 & 0.253 & & \\
\hline Members $\times$ donation & -0.071 & 0.070 & & \\
\hline Education $\times$ donation & -0.203 & 0.220 & & \\
\hline Log likelihood (LL) & $-2,093.03$ & & & \\
\hline LL from standard logit model & $-2,262.24$ & & & \\
\hline
\end{tabular}

Notes: Asc is the alternative specific constant for "neither" option; produce is the fruit/vegetable dummy. Asterisks $\left(* * * * *\right.$, and $\left.{ }^{*}\right)$ denote two-tail statistical significance at the $1 \%, 5 \%$, and $10 \%$ levels, respectively. Number of individuals $=340$. Number of observations $=2,640$.

the simulated demand curves represent the proportion of the population (i.e., market share) willing to pay various price premiums (Louviere, Hensher, and Swait, 2000). Comparing the demand curves reveals that a greater proportion of consumers are willing to pay a positive premium for local fruits and vegetables with a donation $(97 \%)$ than for local animal products with a donation $(84 \%)$. Figure 1 also reveals the market share for animal products drops more rapidly as the percent premium increases than for produce, most likely because of the greater actual dollar cost for a given percentage premium on animal products than for produce products.

\subsubsection{The Effect of Consumer Sociodemographic Characteristics}

Table 5 extends the analysis by presenting a model that includes possible interactions between the main attribute effects of the local and donation 
variables, with the sociodemographic characteristics of respondents. The potential for nonlinear age impacts was also examined using quadratic variable specification, but no evidence of this was found. The following findings are particularly noteworthy: (1) consumers with higher income are willing to pay more for local products and to donate to the food bank program, (2) females have a higher WTP for local products, and (3) older individuals are less willing to pay for local products and products that include a donation to the food banks.

The parameters presented in Table 5 can be aggregated to estimate the impacts that the sociodemographic factors have on mean WTP for products that contain the local and donation attributes. Because the parameters reported in Table 5 reflect their effects on the indirect utility function, they must be rescaled to capture their impact on the WTP price premiums. The estimated coefficients that affect each WTP function (locally grown animal products [produce] with a donation) must be aggregated by the appropriate product type and normalized on the appropriate price coefficients (animal or produce). For example, the intercept for the animal product WTP function with both attributes is calculated as the negative of the sum of the local, donation, and local $\times$ donation parameters divided by the price parameter $(-[1.565+1.323+0.595] /-5.758=0.605)$. By comparison, the intercept for the produce WTP function with both attributes is calculated as the negative of the sum of the local, donation, local $\times$ donation, produce $\times$ local, and produce $\times$ donation parameters divided by the sum of the price parameter and the produce $\times$ price parameter $(-[1.565+1.323+$ $0.595+0.233+0.227] /(-5.758-2.417)=0.482)$. The appropriate parameter aggregation and price normalization for all other estimated parameters generate the two mean WTP functions for animal and produce products and are described by equations (9) and (10), respectively:

$$
\begin{aligned}
& \text { WTP } P_{\text {AnimProd }(\text { local }+ \text { donation })}=0.605+0.131 \text { income } \$ 40 \mathrm{~K}-\$ 80 \mathrm{~K} \\
& +0.194 \text { income }>\$ 80 \mathrm{~K}+0.074 \text { female }-0.007 \text { age }-0.012 \text { white } \\
& -0.060 \text { members }-0.026 \text { education }
\end{aligned}
$$

An equivalent WTP function for produce is

$$
\begin{aligned}
& W_{T P} \text { Produce }(\text { local }+ \text { donation }) \\
& +0.135 \text { income }>\$ 80 \mathrm{~K}+0.052 \text { female }-0.004 \text { age }-0.008 \text { white } \\
& -0.043 \text { members }-0.018 \text { education. }
\end{aligned}
$$

Interpretation of parameters in the derived WTP functions is identical to that in a standard linear regression model. The marginal effects of continuous variables represent the change in the WTP for local products whose price includes a donation to a food system program given a one-unit change in the variable. Thus, each additional year of age decreases the WTP premium by $0.7 \%$ for animal products and $0.4 \%$ for produce. Household size is a significant driver of consumer WTP premium for these local products; each additional household 
member is estimated to decrease the WTP premium by $6.0 \%$ for animal products that are local and include a food system donation and by $4.3 \%$ for equivalent produce.

The marginal effects of dummy explanatory variables are interpreted relative to the dummy variables excluded from the model (a nonwhite male consumer without any college education, who is member of a household that makes less than $\$ 40 \mathrm{~K}$ per year). The results suggest that gender and income have a strong impact on WTP for both products possessing the local and donation attributes. Relative to male consumers, females are willing to pay an additional $5.2 \%$ premium for produce and an additional $7.4 \%$ premium for animal products that are local and include donations.

Relative to respondents with a household income less than $\$ 40 \mathrm{~K}$, those with household income between $\$ 40 \mathrm{~K}$ and $\$ 80 \mathrm{~K}$ are willing to pay $13.1 \%$ more for local animal products and $9.2 \%$ more for local produce with a donation. Consumers with household income greater than $\$ 80 \mathrm{~K}$ are willing to pay $19.4 \%$ more for local animal products with donation and $13.5 \%$ more for local produce that also includes a food bank donation. No economic significant difference in premiums was detected on the basis of race or education.

The estimated WTP functions can also be used to explore potential biases that could be introduced if our sample is not representative of the population. ${ }^{9}$ To do so, mean WTP premium values were calculated for each of the six possible combinations of the two product WTP functions (equations 9 and 10) and three product attributes (local, no donation; donation, not local; and local plus donation). The mean WTP premiums were calculated using the WTP function parameters (Table 5) and the mean population values (from Table 2) for age, income, gender, race, household size, and education. The calculated mean WTP premiums are very similar to the estimated values presented in Table 4. For example, the calculated mean WTP values for the combination of the local and donation attributes for produce and animal products were $21.68 \%$ and $22.23 \%$, respectively. Hence, the estimated mean WTP values do not seem to be affected by the observed differences in the characteristics of the sample and reference population.

9 To assess the sensitivity of the welfare estimates to the estimated method used, we also estimated latent class models (LCMs), which provide an alternative way to account for individual level heterogeneity (Greene and Hensher, 2003; Haynes, Hanley, and Scarpa, 2008). Mean WTP values for each of the product categories shown in Table 4 were estimated using the results of a three-class LCM. Estimated mean WTP values from the LCM were very similar to those shown in Table 4. There were some differences between the approaches regarding the proportion of individuals with negative WTP premiums. Overall, the LCM resulted in a higher proportion of individuals with negative WTP premiums. Evaluation of the effect of sociodemographic characteristics on WTP values derived using LCM has only recently been explored by Hess et al. (2011); therefore, we used the well-established approach of adding sociodemographic characteristics in the mixed logit model to explore this issue. 


\subsection{Donation Preference}

A secondary objective of this research was to determine the type of donation program consumers most preferred-as a known versus unknown (i.e., built-in) proportional amount. Although the donation type could have been incorporated as another product attribute in the choice experiments, focus group analysis revealed that doing so created unnecessary complexity to the experiment description and decreased respondent understanding of the choice experiments. Hence, an additional question was included at the end of the survey to address this issue (see Table A3 in the Appendix).

Knowledge of the known donation amount was overwhelmingly the most popular option; approximately $82.4 \%$ of respondents preferred to know the value of their donation, whereas only $3.9 \%$ of the survey respondents preferred to make a blind donation. The other $13.7 \%$ were undecided. This suggests consumers gain more utility from a known-proportion donation than a blind donation when making a local food purchase.

\section{Conclusions and Future Research}

Demand for locally grown food has significantly increased the past few decades. This research presents an initial examination of the potential for a donation policy that could facilitate the distribution of raw local food products to food retailers. In doing so, consumers would benefit from increased access to locally grown fresh farm products, and local farmers would benefit from the increased revenue that may be generated by this market opportunity. By combining consumer preference for locally grown foods with a food system donation, it may be possible to redefine how consumers donate to food systems in a manner that jointly helps low-income members of their local community while supporting local farmers.

Attribute-based methods were used to estimate how much above their average expenditure on produce and animal products consumers are willing to pay for a locally grown product that is bundled with a donation. Important sociodemographic characteristics that are likely to influence consumer WTP were included in the analysis. A mixed logit model was used to analyze consumer responses to a choice experiment presented to a random sample of households in the upstate region of South Carolina.

Estimates reveal that the average household is willing to pay $11.68 \%$ (\$0.17/lb.) more for locally grown produce and $10.75 \%(\$ 0.33 / \mathrm{lb}$.) more for locally produced animal products relative to those sourced from outside the region. When the locally grown product attribute is combined with a food system donation, the WTP premium increases to $22.33 \%$ (\$0.33/lb.) for produce and $20.50 \%$ (\$0.64/lb.) for animal products. The strong complementary relationship found between the local and donation attributes suggests that consumers have 
a stronger preference to donate when purchasing locally grown products than when purchasing nonlocal products. Consumers are willing to pay only a small price premium for products that offer a food system donation when purchasing products that are not locally grown, 3.69\% (\$0.05/lb.) more for produce and $0.59 \%$ (\$0.02/lb.) more for animal products. As anticipated, WTP for both locally grown products and the magnitude of the donation increase with income. WTP price premiums for local food products that included a donation also increased with educational level and were higher for women than men. WTP decreased with age and household size.

There are several potential implications of these findings. It has been argued that beyond offering direct benefits to both suppliers and consumers of local food products, the enhancement of LFSs may offer many additional direct and indirect benefits to the communities in which they are located; thus, there is the potential for a significant economic multiplier to be generated (Swenson, 2010; Taylor and Miller, 2010). ${ }^{10}$ Other touted benefits include the potential for LFSs to foster economic development through agglomeration and clustering, improve a region's quality of life, stimulate social capital formation, and provide the basis of regional branding strategies (Boys and Hughes, 2013; Glowacki-Dudka, Murray, and Isaacs, 2013).

The additional revenue generated through the type of donation programs evaluated in this study may provide sufficient economic incentive to encourage nonprofit food system intermediaries, such as food banks, to expand the scope of their activities. Doing so would offer these organizations an opportunity to make use of any underutilized capacity and potentially improve their allocation of human and other resources across activities. Further, with such a program in place, the marketing opportunities available to small local farmers will be expanded, and their income and sustainability may be enhanced. This, in turn, could further stimulate the local economy through the multiplier mechanisms described previously. The finding that consumers are willing to pay a premium for locally produced food products if that price includes a donation could also be leveraged usefully by other LFS stakeholders.

Several opportunities exist for extending this research-both adjusting and extending the current research design and examining the interest in adopting this food system policy in other settings. Despite significant efforts made to obtain a random sample and avoid self-selection bias, the low response rate to the survey instrument could potentially lead to inaccurate WTP estimates as a result of nonresponse biases. Although, at a minimum, these results suggest the existence of a niche market for products that are marketed as local and include

10 For example, in their study of Oklahoma farmers markets, Henneberry, Whitacre, and Agustini (2009) estimated multipliers of farmers market job creation of 1.41 to 1.78 . That is, for every job created at a farmers market, $0.41-0.78$ of a second job was generated elsewhere in the local economy. Otto and Varner (2005) reported multipliers of farmer income earned at Iowa farmers markets of 1.47. 
a food system donation, further research is needed to estimate the size of this market. In addition, this research was focused on a particular area of upstate South Carolina; future research could extend this issue to other regions, states, and countries. In addition, the definition of "local" could be adjusted, and the study repeated to assess the robustness of findings to this assumption.

Complementary studies are also needed to determine the level of preparedness of food banks or other potential food system intermediaries to implement the proposed policy and to refine the best models of distributing and marketing these local food products. Alternative models of local food distribution, such as those introduced by Day-Farnsworth et al. (2009) and Matson, Sullins, and Cook (2013), could be considered. As LFS resources and structures vary significantly, it is reasonable to anticipate that the most effective implementation model could also differ from place to place.

Should it be determined that food banks are the most appropriate local food distribution model, adoption of this approach will require further consideration of some marketing and managerial considerations. First, it is possible that some consumers may attach a stigma to food products distributed by LFBs. As such, the use of labels indicating that a product is distributed by an LFB should be carefully evaluated. Further study would also be needed to determine more precisely the depth and type(s) of commitments these organizations need and would be willing and able to make to implement this policy. Results of Robinson et al. (2007) and informal conversations with other food banks suggest they have a willingness to take on these additional marketing channel roles if properly incentivized. Because food banks are nonprofit organizations that, frequently, are largely reliant on volunteers, it is unlikely that the diffusion of this model of an integrated food system would occur as quickly as would be expected from a food system motivated primarily by profit incentives. The proposed system would require a change in the management paradigm, organizational structure, and scope of activities of food banks.

\section{References}

American Express. "Corporate Responsibility: Initiatives-Historic Preservation Initiatives.” Internet site: http://about.americanexpress.com/csr/pip.aspx (Accessed February 15, 2015).

Barham, J., D. Tropp, K. Enterline, J. Farbman, J. Fisk, and S. Kiraly. Regional Food Hub Resource Guide. Washington, DC: U.S. Department of Agriculture, Agricultural Marketing Service, April 2012.

Boys, K.A., and S.C. Blank. "The Evolution of Local Foods: A Retrospective and Prospective Consideration." The Meaning of Local Foods: A Food Marketing Perspective. J. Stanton and M. Lang, eds. Forthcoming.

Boys, K.A., and D.W. Hughes. "A Regional Economics-Based Research Agenda for Local Food Systems." Journal of Agriculture, Food Systems, and Community Development 3,4(2013):145-50. 
Boys, K.A., L. Westray, and A. Fraser. "Southeastern Specialty Crop Producers and Institutional Food Services: Supply Chain Concerns and Considerations." Paper presented at the Agricultural and Applied Economics Association 2012 Annual Meeting, Seattle, Washington, August 12-14, 2012. Internet site: http://ageconsearch.umn. edu/bitstream/124951/2/124951.pdf (Accessed February 15, 2015).

Brønn, P.S., and A.B. Vrioni. "Corporate Social Responsibility and Cause-Related Marketing: An Overview." International Journal of Advertising 20,2(2001):207-22.

Burnett, P., T.H. Kuethe, and C. Price. "Consumer Preference for Locally Grown Produce: An Analysis of Willingness-to-Pay and Geographic Scale.” Journal of Agriculture, Food Systems, and Community Development 2,1(2011):269-78.

Cantor, A., and R. Strochlic. Breaking Down Market Barriers for Small and Midsized Organic Growers. California Institute for Rural Studies, 2009. Internet site: http://ccwiki.pbworks.com/f/CA+Market+Barriers+CIRS+11_09.pdf (Accessed February 15, 2015).

Carpio, C.E., and O. Isengildina-Massa. "Consumer Willingness to Pay for Locally Grown Products: The Case of South Carolina." Agribusiness 25,3(2009):412-26.

Cherchi, E., and J. de Dios Ortúzar. "Empirical Identification in the Mixed Logit Model: Analysing the Effect of Data Richness." Networks and Spatial Economics 8,23(September 2008):109-24.

Curtis, R., S. Presser, and E. Singer. "The Effects of Response Rate Changes on the Index of Consumer Sentiment.” Public Opinion Quarterly 64,4(2000):413-28.

Day-Farnsworth, L., B. McCown, M. Miller, and A. Pfeiffer. Scaling Up: Meeting the Demand for Local Food. University of Wisconsin Extension Agricultural Innovation Center and University of Wisconsin-Madison Center for Integrated Agricultural Systems, December 2009. Internet site: http://www.cias.wisc.edu/ wp-content/uploads/2010/01/baldwin_web_final.pdf (Accessed January 5, 2016).

Dillman, D.A., J.D. Smyth, and L.M. Christian. Internet, Mail, and Mixed-Mode Surveys. 3rd ed. Hoboken, NJ: John Wiley and Sons, 2009.

Dunne, J.B., K.J. Chambers, K.J. Giombolini, and S.A. Schlegel. "What Does 'Local' Mean in The Grocery Store? Multiplicity in Food Retailers' Perspectives on Sourcing and Marketing Local Foods." Renewable Agriculture and Food Systems 26,1(March 2011):46-59.

Ellen, P.S., L.A. Mohr, and D.J. Webb. "Charitable Programs and the Retailer: Do They Mix?” Journal of Retailing 76,3(2000):393-406.

Food, Conservation, and Energy Act of 2008. Pub. L. No. 110-246, 122 Stat. 1651 (2008). Internet site: https://www.gpo.gov/fdsys/pkg/PLAW-110publ246/ pdf/PLAW-110publ246.pdf (Accessed March 31, 2016).

Giraud, K.L., C.A. Bond, and J.J. Bond. "Consumer Preferences for Locally Made Specialty Food Products across Northern New England." Agricultural and Resource Economics Review 34,2(October 2005):204-16.

Glowacki-Dudka, M., J. Murray, and K.P. Isaacs. "Examining Social Capital within a Local Food System." Community Development Journal 48,1(2013):75-88.

Greene, W.H., and D.A. Hensher. "A Latent Class Model for Discrete Choice Analysis: Contrasts with Mixed Logit." Transportation Research Part B: Methodological 37,8(September 2003):681-98.

Hand, M.S., and S. Martinez. "Just What Does Local Mean?" Choices 25,1(2010). Internet site: http://ageconsearch.umn.edu/bitstream/93821/2/2010102\%5b1\%5d.pdf (Accessed April 8, 2016). 
Harvest Astoria. "Frequently Asked Questions." Internet site: http://www.harvestastoria. com/faq/ (Accessed February 15, 2015).

Haynes, S., N. Hanley, and R. Scarpa. "Effects on Welfare Measures of Alternative Means of Accounting for Preference Heterogeneity in Recreational Demand Models." American Journal of Agricultural Economics 90,4(November 2008):1011-27.

Helsing Junction Farm. "Farm: Community Services." Internet site: http://www. helsingfarmcsa.com/farm.php (Accessed February 15, 2015).

Henneberry, S.R., B. Whitacre, and H.N. Agustini. "An Evaluation of the Economic Impacts of Oklahoma Farmers Markets.” Journal of Food Distribution Research 40,3(November 2009):64-78.

Hensher, D., N. Shore, and K. Train. "Households' Willingness to Pay for Water Service Attributes." Environmental and Resource Economics 32,4(December 2005): 509-31.

Hess, S. "Posterior Analysis of Random Taste Coefficients in Air Travel Behaviour Modelling." Journal of Air Transport Management 13,4(July 2007):203-12.

Hess, S., M. Ben-Akiva, D. Gopinath, and J. Walker. "Advantages of Latent Class over Continuous Mixture of Logit Models." Working paper, Leeds, UK: Institute for Transport Studies, University of Leeds, 2011.

Holbrook, A.L., J.A. Krosnick, and A. Pfent. "The Causes and Consequences of Response Rates in Surveys by the News Media and Government Contractor Survey Research Firms." Advances in Telephone Survey Methodology. J.M. Lepkowski, C. Tucker, J.M. Brick, E.D. de Leeuw, L. Japec, P.J. Lavrakas, M.W. Link, and R.L. Sangster, eds. Hoboken, NJ: John Wiley and Sons, 2007, pp. 499-528.

Hoppe, R.A., and J.M. MacDonald. Updating the ERS Farm Typology. Washington, DC: U.S. Department of Agriculture, Economic Research Service, Economic Information Bulletin No. 110, April 2013.

Hughes, D.W., H. Chrissy, and K.A. Boys. "Limehouse Produce: A Unique Wholesaler of Locally Sourced Produce." Journal of Food Distribution Research 45,3(November 2014):58-67.

Hultine, S.A., L.R. Cooperband, M.P. Curry, and S. Gasteyer. "Linking Small Farms to Rural Communities with Local Food: A Case Study of the Local Food Project in Fairbury, Illinois." Community Development 38,3(2007):61-76.

Ilbery, B., D. Watts, S. Simpson, A. Gilg, and J. Little. "Mapping Local Foods: Evidence from Two English Regions.” British Food Journal 108,3(2006):213-25.

Izumi, B.T., O.S. Rostant, M.J. Moss, and M.W. Hamm. "Results from the 2004 Michigan Farm-to-School Survey.” Journal of School Health 76,5(May 2006):169-74.

Keeter, S., C. Kennedy, M. Dimock, J. Best, and P. Craighill. "Gauging the Impact of Growing Nonresponse on Estimates from a National RDD Telephone Survey." Public Opinion Quarterly 70,5(2006):759-79.

King, R.P., M.I. Gómez, and G. DiGiacomo. "Can Local Food Go Mainstream?” Choices 25,1(2010). Internet site: http://ageconsearch.umn.edu/bitstream/ 93824/2/2010105\%5b1\%5d.pdf (Accessed April 8, 2016).

Liu, G., and W.-W. Ko. “An Analysis of Cause-Related Marketing Implementation Strategies through Social Alliance: Partnership Conditions and Strategic Objectives.” Journal of Business Ethics 100,2(May 2011):253-81.

Loureiro, M.L., and S. Hine. "Discovering Niche Markets: A Comparison of Consumer Willingness to Pay for Local (Colorado Grown), Organic, and GMO-Free Products.” Journal of Agricultural and Applied Economics 34,3(December 2002):477-87. 
Louviere, J.J., D.A. Hensher, and J.D. Swait. Stated Choice Methods: Analysis and Application. Cambridge, UK: Cambridge University Press, 2000.

Low, S.A., and S. Vogel. Direct and Intermediated Marketing of Local Foods in the United States. Washington, DC: U.S. Department of Agriculture, Economic Research Service, Economic Research Report No. 128, November 2011.

Marks and Spencer. "Partnerships: Breast Cancer Now." Marks and Spencer, 2015. Internet site: http://corporate.marksandspencer.com/plan-a/our-stories/partnerships/breastcancer-now (Accessed January 5, 2016).

Maryland Food Bank. Farm to Food Bank. Maryland Food Bank, 2015. Internet site: https://mdfoodbank.org/wp-content/uploads/2014/04/FarmToFoodBank_Factsheet.pdf (Accessed May 4, 2016).

Matson, J., M. Sullins, and C. Cook. The Role of Food Hubs in Local Food Marketing. Washington, DC: U.S. Department of Agriculture, Rural Development Service Report 73, January 2013. Internet site: http://www.rd.usda.gov/files/sr73.pdf (Accessed January $5,2016)$

McManus, B., and R. Bennet. "The Demand for Products Linked to Public Goods: Evidence from an Online Field Experiment." Journal of Public Economics 95,5-6(June 2011):403-15.

Onken, K.A., J.C. Bernard, and J.D. Pesek Jr. “Comparing Willingness to Pay for Organic, Natural, Locally Grown, and State Marketing Program Promoted Foods in the MidAtlantic Region.” Agricultural and Resource Economics Review 40,1(April 2011):3347.

Ostrom, M. "Everyday Meanings of 'Local Food': Views from Home and Field." Community Development 37,1(2006):65-78.

Otto, D., and T. Varner. Consumers, Vendors, and the Economic Importance of Iowa Farmers' Markets: An Economic Impact Survey Analysis. Ames: Leopold Center for Sustainable Agriculture, Iowa State University, May 2005.

Pew Research Center. "Assessing the Representativeness of Public Opinion Surveys." Pew Research Center, May 15, 2012. Internet site: http://www.people-press.org/ 2012/05/15/assessing-the-representativeness-of-public-opinion-surveys/ (Accessed February 15, 2015).

Qushim, B., J. Gillespie, K. Paudel, and K. Mcmillin. "Technical and Scale Efficiencies of Meat Goat Farms in the USA.” Applied Economics 48,7(2016):608-20.

Regional Food Bank of Northeastern New York. "Farm: Community Supported Agriculture." Regional Food Bank of Northeastern New York, 2015. Internet site: http://regionalfoodbank.net/farm/community-supported-agriculture/ (Accessed February 15, 2015).

Revelt, D., and K. Train. "Customer-Specific Taste Parameters and Mixed Logit." Working paper, Berkeley: Department of Economics, University of California, Berkeley, 1999.

_. "Mixed Logit with Repeated Choices: Households' Choices of Appliance Efficiency Level." Review of Economics and Statistics 80,4(November 1998):647-57.

Rigby, D., and M. Burton. "Modeling Disinterest and Dislike: A Bounded Bayesian Mixed Logit Model of the UK Market for GM Food." Environmental and Resource Economics 33,4(April 2006):485-509.

Robinson, K.L., K.K. Robinson, C. Carpio, and D. Hughes. "Linking Sustainable Agriculture and Community Development: The Lowcountry Food Bank's Use of Locally Grown Foods." Community Development 38,3(2007):77-89. 
Swanson, A.F. "Small Farmers Aren't Cashing In with Wal-Mart." National Public Radio, February 4, 2013. Internet site: http://www.npr.org/blogs/thesalt/2013/02/04/ 171051906/can-small-farms-benefit-from-wal-mart-s-push-into-local-foods (Accessed February 15, 2015).

Swenson, D. Investigating the Potential Economic Impacts of Local Foods for Southeast Iowa. Ames: Leopold Center for Sustainable Agriculture, Iowa State University, January 2010.

Taylor, D.F., and C.R. Miller. "Rethinking Local Business Clusters: The Case of Food Clusters for Promoting Community Development." Community Development 41,1(2010):10820.

Train, K.E. Discrete Choice Methods with Simulation. New York: Cambridge University Press, 2003.

—_. "Mixed Logit Estimation by Maximum Simulated Likelihood Matlab Code." Internet site: http://elsa.berkeley.edu/ train/software.html (Accessed August 21, 2015).

_. "Recreation Demand Models with Taste Differences over People." Land Economics 74,2(May 1998):230-39.

U.S. Census Bureau. "Selected Characteristics of the Native and Foreign-Born Populations: 2006-2010 American Community Survey 5-Year Estimates.” Internet site: http:// factfinder.census.gov/faces/tableservices/jsf/pages/productview.xhtml?pid=ACS_10_ 5YR_S0501\&prodType=table (Accessed May 10, 2016a).

U.S. Census Bureau. "Selected Characteristics of the Total and Native Populations in the United States: 2006-2010 American Community Survey 5-Year Estimates.” Internet site: http://factfinder.census.gov/faces/tableservices/jsf/pages/productview.xhtml?pid= ACS_10_5YR_S0601\&prodType=table (Accessed May 10, 2016b).

U.S. Department of Agriculture, Agricultural Marketing Service. "Farmers Markets and Direct-to-Consumer Marketing." Internet site: https:/www.ams.usda.gov/ services/local-regional/farmers-markets-and-direct-consumer-marketing (Accessed May 4, 2016).

Varadarajan, P.R., and A. Menon. "Cause-Related Marketing: A Coalignment of Marketing Strategy and Corporate Philanthropy.” Journal of Marketing 52,3(July 1988):58-74.

Vogt, R.A., and L.L. Kaiser. "Still a Time to Act: A Review of Institutional Marketing of Regionally-Grown Food.” Agriculture and Human Values 25,2(June 2008):241-55.

Welsh, J.C. "Good Cause, Good Business." Harvard Business Review 77,5(SeptemberOctober 1999):21-24.

Westray, L. Serving as Suppliers to Institutional Foodservices: Supply Chain Considerations of Small and Medium Scale Specialty Crop Producers. Master's thesis, Clemson University, 2012.

Wooldridge, J.M. Econometric Analysis of Cross Section and Panel Data. Cambridge, MA: MIT Press, 2002. 


\section{Appendix}

Table A1. Example Choice Set

Which would you choose from the options below? (Check only one.)

$\square$ Product A $\square$ Product B $\square$ I would not buy either.

Attribute

Product A Product B

Growing location Out of state Local

Price of product Average price $20 \%$ more than average

Donation None Included

Table A2. Attributes Associated with Each Question and Choice

\begin{tabular}{|c|c|c|}
\hline \multicolumn{3}{|c|}{ Attributes per Choice per Question } \\
\hline $\begin{array}{l}\text { Experiment } \\
\text { Question }\end{array}$ & Choice A & Choice B \\
\hline 1 & $\begin{array}{l}\text { Out of state } \\
\text { Average price } \\
\text { No donation }\end{array}$ & $\begin{array}{l}\text { Out of state } \\
30 \% \text { more than average } \\
\text { Included donation }\end{array}$ \\
\hline 2 & $\begin{array}{l}\text { Local } \\
30 \% \text { more than average } \\
\text { Included donation }\end{array}$ & $\begin{array}{l}\text { Out of state } \\
20 \% \text { more than average } \\
\text { Included donation }\end{array}$ \\
\hline 3 & $\begin{array}{l}\text { Out of state } \\
10 \% \text { more than average } \\
\text { No donation }\end{array}$ & $\begin{array}{l}\text { Out of state } \\
\text { Average price } \\
\text { Included donation }\end{array}$ \\
\hline 4 & $\begin{array}{l}\text { Out of state } \\
10 \% \text { more than average } \\
\text { Included donation }\end{array}$ & $\begin{array}{l}\text { Local } \\
20 \% \text { more than average } \\
\text { Included donation }\end{array}$ \\
\hline 5 & $\begin{array}{l}\text { Local } \\
10 \% \text { more than average } \\
\text { Included donation }\end{array}$ & $\begin{array}{l}\text { Local } \\
\text { Average price } \\
\text { No donation }\end{array}$ \\
\hline 6 & $\begin{array}{l}\text { Out of state } \\
40 \% \text { more than average } \\
\text { No donation }\end{array}$ & $\begin{array}{l}\text { Local } \\
10 \% \text { more than average } \\
\text { No donation }\end{array}$ \\
\hline 7 & $\begin{array}{l}\text { Local } \\
\text { Average price } \\
\text { Included donation }\end{array}$ & $\begin{array}{l}\text { Local } \\
40 \% \text { more than average } \\
\text { No donation }\end{array}$ \\
\hline 8 & $\begin{array}{l}\text { Local } \\
40 \% \text { more than average } \\
\text { Included donation }\end{array}$ & $\begin{array}{l}\text { Out of state } \\
30 \% \text { more than average } \\
\text { No donation }\end{array}$ \\
\hline
\end{tabular}


Table A3. Survey Question Evaluating Consumer Preference for Donation

Please read the explanation of two types of donations that could support a system linking local food banks to local farms. In both cases, donations are included in the sale price, and the buyer knows that he or she is making a donation.

A. Known proportion: a percent of the total purchase of local food is donated to a local food bank. This percentage is explicitly told to the buyer.

B. Blind (built-in donation): a price $x \%$ more than the average price is charged and that $x \%$ is donated. The $x \%$ is unknown to the customer when purchasing. 